\title{
Nilai Karakter dan Religi dalam Berbahasa Kelompok Pupa di Pasar Minggu (Kajian Psikolinguistik)
}

\author{
Khodijah \\ Universitas Indraprasta PGRI \\ Jalan Nangka No. 58 C/TB. Simatupang, Tanjung Barat, Jakarta Selatan 12530 \\ hanemkhadijah@gmail.com
}

\begin{abstract}
The purpose of this research is to find out 1) To find out the character values of pupa groups in Pasar Minggu in the language of psycholinguistic studies. 2). To find out the religious value of pupa groups in Pasar Minggu in language from psycholinguistic studies. The method used in this research is qualitative method. The results of the study concluded: 1). The characters in pupae psycholinguistics at Pasar Minggu after analysis, active participants were 60 members $=100 \%$, the most dominant was Id, there were 49 participants $=65 \%$. The ego of 19 participants $=31.66 \%$. While the superego was only 2 participants $=3.34 \%$. 2). Religion in the pupa group of psycholinguistic studies at Pasar Minggu, that anyone outside of us, has relationships and connectedness, realizing that outside self is a reflection of self. In it taught like: do not hurt each other, do not humiliate each other but praiseworthy qualities such as, mutual respect, respect, and understand the limitations of each self. That is the nature of language.
\end{abstract}

Keywords: Character values, religious values in Pupa group language, psycholinguistic studies.

\begin{abstract}
Abstrak
Tujuan dari penelitian adalah untuk mengetahui 1) Untuk mengetahui nilai karakter kelompok pupa di Pasar Minggu dalam berbahasa dari kajian psikolinguistik. 2). Untuk mengetahui nilai religi kelompok pupa di Pasar Minggu dalam berbahasa dari kajian psikolinguistik. Metode yang digunakan dalam penelitian ini adalah metode kualitatif. Hasil penelitian menyimpulkan: 1). Karakter dalam psikolinguistik kelompok pupa di Pasar Minggu setelah di analisis, peserta yang aktif terdapat 60 anggota $=100 \%$ yang paling dominan adalah Id terdapat 49 peserta $=65 \%$. Ego 19 peserta $=31,66 \%$. Sementara superego hanya 2 peserta $=3,34 \%$. 2). Religi dalam kelompok pupa dari kajian psikolinguistik di Pasar Minggu, bahwasanya siapa pun di luar diri kita, memiliki hubungan dan ketersambungan, menyadari bahwa di luar diri adalah cerminan diri. Di dalamnya diajarkan seperti: tidak saling menyakiti, tidak saling merendahkan melainkan sifat terpuji seperti, saling menghormati, menghargai, serta memaklumi keterbatasan setiap diri. Itulah hakikat bahasa.
\end{abstract}

Kata Kunci: Nilai karakter, nilai religi dalam berbahasa kelompok Pupa, kajian psikolinguistik

\section{PENDAHULUAN}

Berbahasa merupakan rangkaian dari mendengar, bicara membaca dan menulis. Bahasa mempunyai fungsi yang sangat penting bagi manusia, terutama fungsi komunikasi. Manusia mempunyai sistem penggunaan bahasa, sistem ini dapat menjelaskan sesuatu misalnya, bagaimana manusia dapat menyampaikan pikirannya (persepsi bahasa). Setelah menyampaikan pikiran, kemudian mengerti isi pikiran atau makna dari suatu kalimat yang disampaikan lewat tuturan ataupun

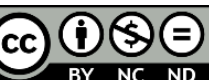

Creative Commons Attribution-NonCommercial-NoDerivatives 4.0 International License 
lewat sebuah tulisan, selanjutnya akal akan mengolah tahapan dan ini terkait dengan kajian psikolinguistik.

Dalam berbahasa penting adanya sebuah rencana, hal ini dikenal dengan istilah perencanaan bahasa, yang tujuannya dengan perencanaan tersebut, tidak akan ada hambatan yang terjadi dalam komunikasi masyarakat di dalamnya. Perencanaan tersebut menyangkut karakteristik bahasa seperti dinamis, yang membuat bahasa itu akan tetap hidup, juga akan mampu berkembang seiring perkembangan kehidupan setiap penggunanya. Bahasa juga sebagai nilai, artinya bahasa yang disampaikan penutur, menggambarkan nilai atau karakter penutur itu sendiri. Bahasa memiliki bahan dokumentasi untuk dikaji. Menurut penulis ini sudah pasti, karena dalam setiap waktunya bahasa selalu berkembang dengan perkembangan tersebut bahasa pun pastinya mengalami perubahan. Sebab inilah menurut penulis bahasa sama sebagaimana halnya manusia, yang juga selalu berproses dalam perkembangannya. Bahasa dan manusia sama-sama keduanya memiliki proses perubahan.

Menyimak begitu penting dan mulianya peran bahasa dalam kehidupan, penulis merasa tertarik untuk mengangkat permasalahan yang seringkali terjadi dengan penutur bahasa itu sendiri. Dalam kenyataannya tidak sedikit penutur bahasa menggunakan bahasa sebagai senjata pertikaian, perselisihan bahkan hujatan. Ini terbukti oleh generasi masa kini. tentunya itu akan berpengaruh terhadap kehidupan yang akan datang. Itulah salah satu sebab penulis mengangkat tema penting ini, dimana dalam realitanya perencanaan bahasa mulia tercoreng oleh kebanyakan para pengujarnya. Maka terbesitlah judul tesis "Nilai Karakter dan Religi dalam Berbahasa Kelompok Pupa di Pasar Minggu: Kajian Psikolinguistik." Judul tesis tersebut mirip sebagaimana tesis yang ditulis oleh saudara Yayan Mulyana, siswa Unindra tahun 2015, hanya saja kajian dan teori yang dibahas saudara Yayan fokusnya pada gaya bahasa, khususnya bahasa sunda. Sementara penulis lebih fokus pada nilai karakter dan religi terkait dengan kajian psikolinguistik. Harapan penulis semoga tulisan ini dapat menyampaikan pesan pada setiap kalangan bahwa, bahasa bukanlah sekadar suara yang keluar mulut semata.

Bahasa merupakan hal mendasar yang memiliki keterkaitan dengan semua bidang. Berkenaan dengan harkat dan martabat seseorang yang jika kita melatihnya maka indahlah semua. Jika tidak, maka kerugianlah yang terjadi. Kesalahan dalam berbahasa tidak layak terjadi, jika penutur memahami hakikat dari bahasa itu sendiri. Shidarta (1984: 148) mengemukakan bahwa, kesalahan berbahasa sering terjadi permasalahannya bukan sebab kerusakan pada organ semata, namun terkait dengan pemikiran seseorang. Tentunya pendapat tersebut sangat sesuai dengan kajian yang penulis tulis. Bagi penulis berbahasa bukan semata-mata hanya soal indra, namun terkait dengan semuanya, sebagaimana telah dikatakan di atas bahwa, bahasa terkait dengan rasa dan juga sikap. Baik sikap penutur ataupun sikap pendengarnya. Penulis sepakat permasalahan bahasa yang sebenarnya, terdapat pada penutur dalam menyikapi respon pendengar. Respon adalah sebab dari semuah masalah. Hal ini terbukti nyata di kelompok rumah pupa. Inilah alasan penulis merasa tertarik dan peduli, kemudian mengangkatnya sebagai kajian kejiwaan 
dalam berbahasa. Kebetulan kajian ini belum ada pada Prodi Bahasa Sastra Indonesia, di Perpustakaan Unindra.

Setelah peneliti meneliti, yang terjadi di kelompok pupa bahwa, kecil besar, baik ataupun tidaknya suatu respon, itu semua berefek luar biasa, Jika semuanya tidak disadari. Begitulah kenyataannya. Kasus yang terjadi merupakan tuntunan setiap diri, artinya kajian ini selayaknya dapat dijadikan sebagai pengantar nilai seseorang dalam membantu mengatasi gejolak jiwa diri yang otomatis berpengaruh pada lingkungan di sekitarnya.

\section{METODE}

Dalam penelitian ini penulis melakukan langka-langkah yang ditempuh untuk memperoleh data diantaranya dengan cara, mendatangi beberapa perpustakaan seperti, perpustakaan Unindra, perpustakaan Nasional, perpustakaan UPI dan perpustakaan Zahra. Selain itu Penulis sendiri membeli beberapa buku yang terkait materi yang akan ditelitinya. Kemudian peneliti menghadiri serta mewawancarai dan mengikuti acara di rumah pupa, sehingga beberapa pertanyaan dapat diketahui dengan jelas. Catatan yang peneliti catat tersebut dikumpulkan menjadi satu, kemudian peneliti mengolah kembali. Tujuan pengolahan tersebut agar permasalahan yang terkait sesuai dengan beberapa teori yang akan dikaji di dalamnya, sehingga dapat diketahui dari ketiga teori itu memang memiliki keterkaitan.

Metode kualitatif adalah, suatu pendekatan yang disebut sebagai investigasi, sebab diperlukan waktu dalam pengamatan khusus dari sebuah kasus. McMullan dan Schumacher (2003: 73) menyatakan, dengan penelitian kualitatif seorang peneliti akan meneliti dan menggambarkan setiap individu dalam kehidupan dan pemikirannya. Seorang peneliti akan mampu menjelaskan apa yang ditelitinya itu.

Penelitian kualitatif mengasumsikan realita sebagai sesuatu yang dapat dilihat dari sudut pandang yang berbeda, interaksi dengan individu dan pengalaman peristiwa dipahami berdasarkan pemahaman subjektif.

Pendekatan kualitatif adalah, pendekatan yang penting dalam memahami suatu fenomena atau pun permasalahan individu yang memang perlu untuk dikaji. Tentunya dalam melakukan penelitian tersebut peneliti ikut terlibat dalam situasi yang ada di dalam kelompok pupa. Di dalam kegiatan kelompok pupa peneliti mengamati serta menginterprestasikan dengan kenyataannya. Berikutnya peneliti akan menyinkronkan permasalahan yang ada dengan ketiga kajian teori yang telah dipilih, seperti teori behavioristik, teori Sigmund Freud dan teori Sufime.

Hasil penelitian ini bukan hanya sebatas untuk memenuhi gelar magister semata, melainkan mampu mengantar setiap penutur bahwa, hakikatnya bahasa adalah, memahami setiap kekurangan yang ada dalam diri, dengan demikian seseorang akan mudah saling memaklumi, dimana kekurangan yang ada menjadikan setiap diri akan saling melengkapi.

langkah lain yang dilakukan peneliti adalah, melakukan pendekatan penelitian dengan cara, mencatat, merekap, memotret, merekam semua yang disaksikan pada saat datang, baik saat menghadiri acara ataupun pada saat di luar

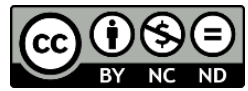


acara. Kemudian peneliti mewawancarai ibu pembina yang juga sebagai para psikolog yang dilakukan peneliti ia melakukan pencatatan semua informasi yang di dapat, mendengar pada saat klien sedang berkonsultasi dan terapi, mengikuti acara rutin meditasi yang dilakukan pupa, menyimak setiap materi yang disampaikan, Serta mengikuti ibu pembina apabila akan menghadapi pasiennya.

Populasi sebagai subjek penelitian ini adalah kelompok pupa adapun sampelnya peneliti mewawancarai mereka, beberapa orang yang dalam permasalahan dengan dirinya sendiri, juga dengan lingkungan keluarga, dengan rekan kerja, bahkan dengan pasangannya juga. Tidak lain sebab dari semua masalah adalah respons dari sebuah tuturan.

Peneliti mengambil sebagian sampel untuk mewakili anggota kelompok pupa yang di dalamnya terdapat dalam dua kelompok, yaitu kelompok luar dan kelompok dalam. Kelompok dalam adalah ia yang aktif mengikuti informasi dan acara rutin bulanan di dalamnya. Sementara anggota luar mereka yang tidak mengikuti acara di dalam kegiatan yang ada, hanya saja bisa mengundang ibu Hana untuk mengisi acara mereka, bisa berkonsultasi dan lainnya. Jumlah keseluruhan anggota pupa jika digabungkan kurang lebih sekitar seribu orang. Penanganan yang dilakukan pembina pupa kurang lebih sama, yaitu berpusat pada bagaimana cara merespons dan untuk tidak mudah memberi respons. Satu cara yang diajarkan pupa yaitu, dengan melakukan pengamatan pikiran sendiri, yakni melakukan meditasi. Peneliti menentukan sampel yang ada dengan cara melakukan pengamatan pada peserta semua. Kemudian peneliti memutuskan untuk menjadikannya sebagai target.

Hasil penelitian sebagai sumber analisis yang diperoleh dari pertemuan peneliti setelah wawancara dengan ibu pembina, kemudian di saat pasien yang sedang berkonsultasi, mengutarakan masalah yang sedang dialami, peneliti mengamati yang dikeluhkan peserta juga mengamati ucapan pembina pupa pada saat menyampaikan pesan dan materi yang diajarkan pupa.

\section{HASIL DAN PEMBAHASAN}

Kajian yang diteliti penulis adalah kajian psikolinguistik, menitikberatkan pada teori Sigmund Freud terkait dengan psikoanalisis diantaranya: id, ego, dan superego. Behavioristik terkait respons positif dan respons negatif dan sufisme.

Tabel 1. Persentase Psikoanalisis Sigmund Freud pada Kelompok Pupa di Pasar Minggu

\begin{tabular}{cccc}
\hline No & Aspek Psikologis & Temuan & Persentase \\
\hline 1 & Id & 39 & $65 \%$ \\
2 & Ego & 19 & $31,66 \%$ \\
3 & Superego & 2 & $3,34 \%$ \\
& Jumlah & 60 & $100 \%$ \\
\hline
\end{tabular}

Dari tabel di atas terlihat bahwa aspek psikologis penutur bahasa dalam kelompok pupa yang paling dominan adalah aspek id dengan persentase sebesar 
$65 \%$ dengan 39 penemuan. Kemudian aspek ego dengan persentase sebesar 31,66\% dengan 19 penemuan, diikuti dengan aspek superego dengan persentase sebesar $3,34 \%$ dalam 2 penemuan.

Sesuai apa yang disampaikan peneliti, bahwa tujuan penelitian ini dilakukan agar terjalinnya sikap kasih dalam berbahasa. Dimana satu dengan yang lain saling melengkapi ketidaksempurnaan diri. Dalam rangka penelitian ini, penulis mencatat kemudian menganalisis tiga kajian teori yang diantaranya yaitu, Tiga aliran psikoanalisis, yang dikembangkan Sigmund Freud, secara tegas memperhatikan jiwa manusia, fokus aliran ini adalah totalitas, terkait dengan kepribadian manusia, bukan pada bagian-bagian yang terpisah. Menurut aliran ini, perilaku manusia dianggap sebagai hasil interaksi sub sistem dalam kepribadian manusia. Kedua adalah aliran bihavioristik yaitu, antara sadar dan tidak sadar. Ketiga, aliran sufisme. Semoga ini mampu menjelaskan kajian yang sedang penulis teliti, yaitu psikolinguistik. Penulis telah menyimak dari pemikiran ketiga teori tersebut, sesuai bagaimana yang diajarkan pada kelompok pupa. Satu dengan yang lainnya memiliki keterkaitan. Ini menggambarkan bahwa ketiga teori, antara bagian psikoanalisis, dengan pemahaman kaum behavioristik yang terkait dengan laku manusia, ada ketersambungan, antara Sigmund Freud dan psikologi yang dikembangkan oleh Jhon B. Watson. Pada tahun 1913 dikembangkan oleh Burhus Fredderick Skinner. Aliran behavior lahir sebagai reaksi dalam menganalisis jiwa manusia dan berdasarkan laporan-laoran subjektif, juga aliran psikoanalisis (berbicara tentang alam bawah sadar yang tidak nampak), sementara aliran behavioristik hanya membicarakan tingkah laku yang nampak, dapat di ukur, dilukiskan dan diramal. Teori ini dikenal dengan teori belajar. Asumsi dari aliran ini adalah seluruh perilaku manusia merupakan hasil belajar. Aliran behavioristik mempersoalkan bagaimana perilaku manusia dikendalikan oleh faktor-faktor lingkungan. Walaupun demikian, asumsi yang digunakan oleh aliran behaviorisme banyak menentukan perkembangan psikologi. Salah satu yang muncul dalam literatur psikologi adalah tentang tabularasa (fitrah manusia), sebagai kelanjutan tentang pendapat aristoteles yang secara garis besar menganalogikan manusia (bayi) sebagai kertas putih dan yang menjadikannya hitam atau berwarna lain adalah pengalaman atau hasil interaksinya dengan lingkungan. Teori plaziman klasik, teori plaziman operan, dan social learning theory juga merupakan produk dari aliran ini, disebabkan oleh respons baik dan tidak, begitu juga yang disampaikan Hana as dalam kelompok pupa terkait dengan ajaran sufisme.

Tabel 2. Hasil Analisis Psikoanalisis Sigmund Freud Pada Kelompok Pupa di Pasar Minggu

\begin{tabular}{lllllll}
\hline No & Psikoanalisis & Transkrip & sikolinguistik & $\begin{array}{c}\text { Nilai } \\
\text { Karakter }\end{array}$ & $\begin{array}{c}\text { Nilai } \\
\text { Religi }\end{array}$ \\
\hline 1 & Id & $\begin{array}{l}\text { Kesadaran } \\
\text { lemah }\end{array}$ & $\begin{array}{l}\text { Menderita } \\
\text { ketakutan }\end{array}$ & Terbungkus & Abangan \\
& & $\begin{array}{l}\text { Sadar } \\
\text { siaga } \\
\text { (ingatan } \\
\text { siap) }\end{array}$ & $\begin{array}{l}\text { Belajar } \\
\text { menerima }\end{array}$ & $\begin{array}{l}\text { Kemerdekaan } \\
\text { sesaat }\end{array}$ & Priyayi \\
& Ego & & & & \\
& & & & &
\end{tabular}




3 Superego Sadar $\quad \begin{aligned} & \text { Bahagia } \\ & \text { (Ikhlas) }\end{aligned} \quad$ Cinta kasih $\quad \begin{aligned} & \text { Santri } \\ & \text { (sufisme) }\end{aligned}$

Gambaran di atas dapat di lihat dari beberapa tahapan perkembangan kehidupan manusia. Seiring dengan kegiatan belajar mereka. Tugas belajar muncul dalam setiap fase perkembangan. Idealnya perkembangan itu berlaku secara otomatis. Adapun fase di atas itu terjadi pada fase umum. Seseorang dikatakan dewasa bukan sekadar di lihat dari kematangan fisiknya, namun jiwanya juga. Kematangan tersebut akan terwujud dengan adanya tuntutan lingkungan sekitar dan juga masyarakat. Contoh id. Seorang ibu bertanya kepada Hana as tentang sikap protesnya kepada Tuhan, sebab kesulitan yang sedang dialaminya tidak pernah selesai. Beliau menganggap bahwa Tuhan sedang memberinya hukuman. Cara ibu itu menerjemahkan tentang Tuhan sangat dangkal, sehingga dia menggambarkan seolah-olah Tuhan seperti mahluk. Kesadaran orang tersebut sangat lemah, sehingga sikapnya terus dihantui rasa takut dan merasa menderita sepanjang hidupnya. memiliki karakter terbungkus, maksudnya pribadi yang tertutup dengan rasa kecewa. hingga dikatakan sebagai kelompok yang memiliki nilai religi abangan.

Tahapan dalam perkumpulan rumah pupa adalah kelompok dewasa. Dimana kedewasaan yang sebenarnya tidak hanya dilihat dari usia. Seperti ibu yang dicontohkan di atas, beliau sudah berusia sekitar 45 tahun, namun melihat perkembangan psikologisnya seperti anak usia remaja. Menurut Hurlock kategori dewasa diantaranya:

1) Dewasa awal (21-40) tahap ini adalah penyesuaian terhadap pola-pola hidup baru dan harapan mengembangkan sifat-sifat serta nilai-nilai yang serba baru. Pada tahap ini seseorang diharapkan menikah, mempunyai anak, mengurus keluarga, membangun karier dan mencapai satu prestasi.

2) Dewasa menengah (40-60) tahapan dewasa menengah merupakan masa transisi, masa menyesuaikan kembali masa equilibrium-disequilibrium. Masa yang ditakuti karena mendekati masa tua. Wanita pada masa ini kehilangan kemampuan berproduksi. Ada yang mengatakan masa ini adalah masa berbahaya bagi pria dan wanita. Dalam pandangan penulis masa ini dimana masa selayaknya sudah harus tau tujuan hidup yang sebenarnya.

Secara garis besar peristiwa perkembangan mempunyai prinsip-prinsip (Yusuf, 2002: 203). Perkembangan merupakan proses yang tidak pernah berhenti. Manusia terus berproses sepanjang hidupnya. Setiap aspek perkembangan pribadi atau individu dipengaruhi dengan yang lainnya. Setiap orang memiliki tempo kecepatan perkembangannya yang berbeda. Setiap individu ingin terus mengembangkan dirinya. Setiap perkembangan dipengaruhi pembawaan setiap individu sejak lahir sampai dewasa, juga berpengaruh dari lingkungannya, sebagaimana contoh ibu di atas. Menurut behavior terkait antara sadar dan tidak sadar. Dikatakan sadar seseorang menyadari kelemahan ataupun ego dirinya. Contohnya, ketika seorang ibu menegur anaknya karena setiap saat bergantung pada hendpon-nya. Respons anak tersebut bahwa, ibunya juga setiap saat, menjadikan sosial media bagian dari keseharian ibu, mendengar hal demikian ibu 
tersebut terkejut. Kemudian ibu sadar bahwa sikap anaknya tidak lain cermin dari sikapnya sendiri. Sehingga ia yang mulanya tidak menyadari menjadi sadar. Inilah contoh sadar siap (ego). yakni belajar menerima, sekalipun teguran tersebut dari sosok dibawa kekuasaannya. Sikap orang tersebut memiliki jiwa yang terbuka, nilai religi kelompok tersebut dalam pandangan penulis adalah golongan priyayi.

\section{Analisis Behavior pada Kelompok Pupa di Pasar Minggu}

\begin{tabular}{lll}
\hline & Teori behavior & \\
\hline Sadar (positif) & & Tidak sadar (negativ) \\
Melakoni & Tidak melakoni \\
\hline
\end{tabular}

Adapun struktur kejiwaan yang ketiga menurut Sigmund Freud adalah superego, terkait dengan teori behavior yang membicarakan soal kelakuan seseorang. Dimana tindakan seseorang dalam melakukan sesuatu sebab sadar dan ketidaksadarannya. Contoh, seorang ibu yang baru saja sembuh dari setruk, sementara kedua anaknya tidak tinggal bersama, beliau tidak menuntut, sebab menyadari bahwa anak-anaknya memiliki tanggung jawab pada keluarganya. Sekalipun demikian hidup beliau tetap bahagia dan menikmati kehidupannya padahal beliau hanya tinggal seorang diri. Aktivitasnya hanya pergi dari majlis satu ke majlis lainnya. Ini adalah salah satu contoh superego atau kesadaran seseorang, sikap orang seperti ini selalu bahagia dan mensyukuri hidupnya, memiliki karakter cinta kasih.

\section{Analisis Data Nilai karakter dan Religius}

Teknik analisis yang digunakan data ini mengalir dengan cara pengumpulan data serta wawancara. Unsur sadar digambarkan seperti contoh di atas. Tingkat kesadaran yang berisi semua hal yang kita cermati hanya pada saat tertentu. Menurut Sigmund Freud hanya sebagian kecil saja dari kehidupan mental (persepsi, perasaan dan ingatan) yang masuk ke kesadaran consciousness atau ingatan siap.

Prasadar disebut juga ingatan siap (available memory), yakni tingkat kesadaran yang menjadi jembatan antara sadar dan tidak sadar. Pengalaman yang ditinggal oleh perhatian, semula disadari tetapi kemudian tidak lagi dicermati, akan ditekan pindah ke daerah prasadar. Seperti halnya yang dicontohkan seorang ibu kedua.

Tak sadar adalah bagian yang paling dalam dari struktur kesadaran dan menurut Sigmund Freud merupakan bagian terpenting dari jiwa manusia. Secara khusus Freud membuktikan bahwa, ketidaksadaran bukanlah abstraksi hipotetik, tetapi itu adalah kenyataan empirik. Ketidak sadaran itu berisi insting, impuls dan drives yang dibawa dari lahir dan pengalam-pengalaman traumatik (biasanya pada masa anak-anak), yang ditekan oleh kesadaran dipindah ke daerah tak sadar atau pun sadar.

\section{Wilayah Pikiran}

Dalam struktur yang digambarkan Sigmund Freud, seperti di bawah ini yang ketiganya terkait dengan behavior, yaitu melakoni sebab kesadaran, tidak melakoni 
sebab ketidaksadaran. Sementara ego hanya jembatan yang memperantarai kedua itu.

Seseorang akan memberikan tanggapan atau respons, baik respons positif maupun respons negatif, keduanya itu tidak terlepas dengan nilai dan karakter seseorang. Tentunya itu terlibat dengan religi yang merupakan bagian sentral juga. Terakhir adalah contoh orang yang ingatannya telah siap, ia telah menyadari, kemudian ia sudah melakoni lakunya sesuai aturan-aturan, karakter terpuji. Orang tersebut dinilai baik bagi penilaian di luar diri (orang lain). Sementara bagi diri, hidupnya hanya pembenahan diri saja. Ia menyadari bahwa di luar diri adalah cermin dirinya sendiri, inilah yang dikatakan arif atau arif billah (superego). Hidupnya hanya berbagi kasih demi meraih cinta-Nya.

\section{SIMPULAN}

1. Karakter dalam psikolinguistik kelompok pupa di Pasar Minggu setelah di analisis, peserta yang aktif terdapat 60 anggota $=100 \%$ yang paling dominan adalah Id terdapat 49 peserta $=65 \%$. Ego 19 peserta $=31,66 \%$. Sementara superego hanya 2 peserta $=3,34 \%$.

2. Religi dalam kelompok pupa dari kajian psikolinguistik di Pasar Minggu, bahwasanya siapa pun di luar diri kita, memiliki hubungan dan ketersambungan, menyadari bahwa di luar diri adalah cerminan diri. Di dalamnya diajarkan seperti: tidak saling menyakiti, tidak saling merendahkan melainkan sifat terpuji seperti, saling menghormati, menghargai, serta memaklumi keterbatasan setiap diri. Itulah hakikat bahasa

\section{DAFTAR PUSTAKA}

Al-Tirmidzi, A. (2011). Biarkan hatimu bicara. Jakarta: PT Zaman.

Al-Jauziyyah, I. Q. (2013). Terapi mensucikan jiwa. Jakarta: Qisthi press.

Arifin, Z. (2017). Psikolinguistik. Tangerang: PT Pustaka mandiri.

Ar, S dan Damianti, V. (2015). Metode penelitian berbahasa. Jakarta: PT Rosda karya.

Cangra, H. H. Pengantar ilmu komunikasi. Jakarta: PT Raja grafindo persada.

Chaer, A. (2015). Linguistik umum (bahasa itu manusiawi). Jakarta: Rieneka cipta.

Dardjowidjojo, S. (2016). Psikolinguistik (pengantar pemahaman bahasa manusia) Jakarta: Pustaka obor Indonesia.

Fazeli, A. S. (2016). Mazhab Ibn Arabi. Jakarta: Sadra press.

Ghozali, A. (2012). Psikologi islam. Jakarta: PT Saadah cipta mandiri.

Hidayat, A. A. (2006). Mengungka hakikat bahasa (makna dan tanda). Jakarta: PT Rosda karya.

Hidayatullah, F. (2010). Pendidikan karakter membangun bangsa. Surakarta: Yuma pustaka.

Khumayni, I. (1995). 40 Hadis. Bandung: Mizan

Maarif, Z. Logika komunikasi. Jakarta: PT Raja grafindo persada. 
Mansur, H. (2014). Psikologi ibu dan anak. Jakarta: Salemba Medika.

Markhama, dkk. (2008). Analisis kesalahan dan kesantunan berbahasa. Surakarta: Muhammadiyah university press.

Mindero, A. (2016). Sikologi sastra. Jakarta: Yayasan obor Indonesia

Moleong L. J. (2016). Metodologi penelitian kualitatif. Bandung: PT Remaja rosda karya.

Mulyana, Y. (2015). Tesis (Analisis psikolinguistik, nilai karakter dan religi dalam berbahasa sunda). Jakarta: Universitas Unindra.

Murthahhari, M. (2001). Manusia sempurna. Jakarta: Lentera

Muslich, I. O. (2010). Perencanaan bahasa (pada era globalisasi). Jakarta: PT Bumi putra aksara.

Nur, S. (2012). Energy Ilahi. Jakarta: Republika.

Panyavaro, S. (2009). Meditasi mengenal diri. Jogjakarta: Suwung.

PGRI, I. U. (2018). Jurnal deiksis. Jakarta: Universitas indraprasta.

PGRI, I. U. (2018). Panduan penulisan sekriso dan tesis. Jakarta: Unindra press.

Rakhmat, J. (2012). Menyesap kearifan al-qur'an melalui tafsir bil ma'tsur. Bandung: PT Mizan pustaka.

Shadra, M. (2004). Manifestasi Ilahi. Bandung: Pustaka hidaya.

Sain, S. (2007). Renungan malam keagungan. Jakarta: Kdf.

Thurab. (2018). Di pintu fana Sukma menemu cinta. Jakarta: Mata Aksara.

Valluddin, M. (1996). Zikir dan kontemplementasi dalam tasawuf. Bandung: Pustaka hidaya

Zuriah, N. (2015). Pendidikan moral dan budi pekerti dalam perspektif perubahan. Jakarta: PT Bumi aksara. 